\title{
DOKTRIN NASIONALISME DALAM NOVEL A. HASJMY
}

\author{
Wildan
}

Email: agamphonna@yahoo.com

Jurusan Bahasa dan Sastra Indonesia Universitas Syiah Kuala

Alamat Korepondensi: Jalan T. Nyak Arief Darussalam Banda Aceh 23111

\begin{abstract}
This study discusses nationalism that has been portrayed in seven novels written by A. Hasjmy, an Acehnese writer. The novels are Melalui Jalan Raya Dunia (1938), Bermandi Cahaya Bulan (1939), Suara Azan dan Lonceng Gereja (1940), Nona Pressroom (1951), Elly Gadis Nica (1951), Meurah Djohan: Sultan Aceh Pertama (1976), and Tanah Merah: Digul Bumi Pahlawan Kemerdekaan Indonesia (1976). The aim of the study is to analyze doctrine of nationalism in the context of Indonesian politics. The main finding of this study shows that Indonesian nationalism is obviously well represented in the novels. This finding is contrary to the public opinion that most of the Acehnese are supporters of the separatist movement, i.e. Acehnese nationalism. Thus, in portraying the nationalism, A. Hasjmy has exploited certain writing techniques in his novels, such as epistolary, speeches, diary, poems and footnotes to camouflage its doctrines and missions. With these findings, the significance of this study is it could elucidate academically that not every Acehnese agrees with the idea of Aceh separatism.
\end{abstract}

\section{Keywords}

Doktrin, Nasionalisme, Novel, A. Hasjmy

\section{Pendahuluan}

Kajian ini meneliti kandungan karya-karya kreatif A. Hasjmy, seorang penulis yang prolifik di Aceh. A. Hasjmy banyak menghasilkan karya kreatif dibandingkan pengarang lain di Aceh. Bahkan, beliau adalah pengarang tunggal di zamannya, yaitu masa Angkatan Pujangga Baru. Karya-karya kreatifnya, terutama novel, turut menyampaikan persoalan dan pesan tertentu seperti gagasan kebangsaan kepada khlayak. Justru, kajian ini difokuskan untuk meneliti nasionalisme yang tergambar dalam ketujuh buah novel yang beliau hasilkan. Ketujuh buah novel yang dikaji itu ialah Melalui Jalan Raya Dunia (MJRD 1938), Bermandi Cahaya Bulan (BCB, 1939), Suara Azan dan Lonceng Gereja (SALG 1940), Nona Pressroom (NP 1951), Elly Gadis Nica (EGN 1951), Meurah Djohan: Sultan Aceh Pertama (MJ 1976), dan Tanah Merah: Digul Bumi Pahlawan Kemerdekaan Indonesia (TM 1976).

Kajian ini bertujuan melihat wajah nasionalisme yang dianut oleh A. Hasjmy, baik nasionalisme yang mendukung negara-bangsa Indonesia (keindonesiaan) ataupun nasionalisme yang ingin mendirikan Aceh sebagai sebuah negara tersendiri (keacehan). Persoalan nasionalisme yang demikian penting dikaji karena isu kaitan antara nasionalisme yang bersifat keindonesiaan dan keacehan merupakan isu yang selalu hangat dibicarakan, baik sebelum ataupun setelah kemerdekaan Indonesia. Sepanjang sejarah, Aceh terus menjadi persoalan bagi pemerintah Indonesia karena Aceh terus menuntut otonomi mutlak. Justru, persoalan nasionalisme yang diungkap dalam karya sastra di Aceh, khususnya dalam karya-karya A. Hasjmy, dapat menentukan posisi pengarang dalam kaitan antara nasionalisme keindonesiaan atau keacehan itu.

Kajian ini secara eklektik menggunakan konsep nasionalisme dari para pakar seperti Benedict Anderson (1999 \& 2002), Hans Kohn (1965), Anthony D. Smith (2001), K.R. Minogue (1967), John Breuilly (2005). Di samping itu, kajian ini juga berpedoman kepada beberapa peneliti yang secara khusus meneliti nasionalisme Indonesia seperti Goerge M. Kahin (1995) dan Sartono Kartodirdjo (1993).

Secara etimologi, nasionalisme berasal dari nation 'bangsa'. Menurut Anderson (1999), bangsa adalah suatu komunitas politik yang direkabayangkan (imagined community). Bangsa dikatakan sebagai sesuatu yang direkabayangkan karena para anggota bangsa itu sering tidak saling mengenal satu sama lain, tidak saling bersemuka, bahkan mungkin tidak pula pernah mendengar satu sama lain, meskipun dalam 
pikiran mereka hidup sebuah bayangan tentang kebersamaan mereka. Jadi, komunitas sejati itu tidak ada. Dalam kenyataan, semua komunitas adalah imaginatif.

Menurut Anderson (1999), nasionalisme hadir dalam pelbagai aspek seperti taman makam pahlawan, makam prajurit yang tidak dikenal dan cenotaph (tugu peringatan bagi para tentara yang gugur dan dikuburkan di tempat lain), lagu kebangsaan, bendera nasional, kesamaan bahasa ibu, kesepahaman bahasa agama, pandangandunia tentang agama, gambar-gambar (ukiran, lukisan, atau sketsa), dan seterusnya. Hal-hal seperti inilah yang disebut sebagai akar-akar budaya nasionalisme. Dengan akar-akar budaya itulah direkabayangkan hal-hal yang bersifat imaginatif sehingga menjadi sangat nyata karena sifat audio-visualnya. Anderson menunjukkan dua bentuk pembayangan itu, yaitu novel dan surat khabar. Kedua wahana itu secara teknikal dapat menampilkan 'keterwakilan' atau 'mengkinikan kembali' komunitas imaginatif yang disebut sebagai bangsa. Dengan itu, Anderson membuat kesimpulan bahwa nasionalisme merupakan sesuatu yang diciptakan dan ia memberi tinjauan terhadap masa silam sekaligus memberi bayangan terhadap masa depan.

Teori Anderson yang abstrak tersebut dijelaskan melalui tinjauan yang ringkas (1999:35-45) terhadap empat buah novel, yang kesemuanya menekankan keserempakan (simultanitas) waktu bagi kelahiran komunitas imajinasi yang disebut bangsa itu. Pertama, novel Noli Me Tangere (1887) karya berbahasa Sepanyol Jose Rizal (Anderson, 2002:3). Melalui novel ini Anderson menunjukkan bahwa antara latar waktu 'interior' novel dan waktu 'eksterior' kehidupan nyata memberi citra hipnotik akan kepaduan sebuah komunitas tunggal, yang merangkul semua orang; watak (novel), penulis, maupun pembaca (Manila). Kedua, novel Pinagdaanang Buhay ni Florente at ni Laura sa Cahariang Albania 1861) karya berbahasa Tagalog oleh Francisco Balagtas. Kisah rekaan itu mengenai Florante, seorang lakilaki bangsawan Albania yang beragama Kristen dan sahabat karibnya Aladin, seorang ningrat Muslim dari Persia. Di sini, Anderson juga menunjukkan teknik bercerita Balagtas, yaitu berupa bait-bait kuatrin sebanyak 399, yang penyingkapan ceritanya tidak tunduk kepada urutan kronologis, melainkan in medias res, dalam serangkaian percakapan yang berfungsi sebagai kilas balik. Ketiga, novel El Periquillo Sarniento (1861) karya sastra Amerika Latin dari Jose Joaquin Fernandez de Lizardi. Melalui novel ini Anderson menunjukkan bahwa 'imajinasi nasional' dalam lanskap sosiologi dilukiskan dengan memadukan dunia novel dengan dunia nyata. Ia berisikan dakwaan tajam atas pemerintahan kolonial Sepanyol di Meksiko, yang melahirkan kebodohan, tahyul, dan rasuah. Terakhir, novel Semarang Hitam (1924) karya berbahasa Indonesia dari Mas Marco Kartodikoro. Melalui novel itu Anderson menunjukkan bahwa fenomena sosial yang hadir melalui watak tidak bernama "laki-laki muda kita" boleh mewakili tubuh kolektif "orang-orang Indonesia" atau merujuk kepada "komunitas imajinatif' Indonesia.

Jauh sebelum itu Kohn (1965:9-10) telah menyatakan bahwa suatu bangsa memiliki faktor-faktor objektif tertentu yang membuat mereka itu berbeda dari bangsa lain, seperti persamaan keturunan, bahasa, daerah, kesatuan politik, adat-istiadat dan tradisi, atau agama. Tiada satu pun di antara faktor-faktor itu yang bersifat hakiki dalam merumuskan bangsa. Meskipun faktor-faktor itu penting, tetapi unsur terpenting ialah kemauan bersama. Kemauan inilah yang dinamakan nasionalisme, yaitu suatu paham atau doktrin yang berpendapat bahwa kesetiaan tertinggi individu diserahkan kepada negara-bangsa.

Selanjutnya, Smith (2001:5-9) memerikan definisi kerja nasionalisme sebagai suatu pergerakan ideologi untuk mencapai dan memelihara otonomi, kesatuan, dan identitas untuk suatu populasi yang sebahagian anggotanya mempertimbangkan untuk membuat satu "bangsa" yang nyata. Menurut Smith, ketiga hal itulah yang menjadi doktrin nasionalisme. Otonomi nasional merupakan sesuatu yang berkaitan dengan upaya mengatur diri sendiri (self-regulation), menentukan nasib sendiri (selfdetermination), memiliki undang-undang dan aturan sendiri, mendengar suara batin sendiri, memiliki kebebasan dari segala tekanan asing, dan bebas dalam berpolitik. Otonomi nasional dapat berupa otonomi total, dalam bentuk negara berdaulat, atau otonomi parsial, dalam bentuk pemerintahan federal. Kesatuan nasional dapat berupa kesatuan wilayah, kesatuan bangsa secara sosial dan budaya. Kesatuan atau persatuan mencerminkan konsep dan proses integrasi berdasarkan kebersamaan (solidarity) nasional yang melampaui kebersamaan kedaerahan (local) dan etnik. Identitas nasional menunjukkan kesamaan di dalam suatu objek pada suatu waktu dan ketetapan suatu pola khas di dalam periode tertentu. Masing-masing bangsa memiliki kaitan dengan sejarah budaya yang unik, cara-cara khas dalam berpikir, bertindak, dan berkomunikasi yang menjadi milik bersama bagi semua anggota bangsa. Tugas para nasionalis, jika budaya unik itu hilang atau dilupakan, adalah menemukan kembali budaya cendekia dari bangsanya dan 
mengembalikan identitas budaya yang otentik bagi rakyat. Menurut Smith, identitas nasional merupakan kesinambungan reproduksi dan penerjemahan kembali terhadap nilai, simbol, kenangan, mitos, dan tradisi yang membentuk warisan bangsa yang unik, serta identifikasi individu dengan pola dan warisan tersebut beserta unsur-unsur budayanya.

Berdasarkan pendapat-pendapat pakar tersebut peneliti mendefinisikan nasionalisme sebagai suatu paham atau gagasan atau konsep, suatu perasaan atau kesadaran, dan suatu gerakan kebangsaan yang memperlihatkan proses pembentukan atau pertumbuhan negara-bangsa dalam menjelmakan kemauan dalam mencapai, mempertahankan, dan mengabadikan kewujudan suatu bangsa. Kajian ini dibatasi pada doktrin nasionalisme, yaitu prinsip atau paham atau konsep yang menjadi asas bagi paham kebangsaan yang dianuti oleh pengarang seperti aspek otonomi, kesatuan, kesamaan, dan identitas nasional.

\section{Latar Kepengarangan}

A. Hasjmy adalah seorang sastrawan Aceh yang sangat terkenal dan prolifik. Beliau adalah sastrawan, juga negarawan, yang menjadi saksi dan pelaku sejarah sejak masa penjajahan hingga setelah kemerdekaan Indonesia. Sebagai pengarang yang prolifik beliau menulis karya sastra yang merefleksikan latar zaman dan latar belakang dirinya sendiri. Beliau merefleksikan semangat kebangsaan atau semangat kenegaraan dalam karya-karya itu. Semangat kebangsaan atau kenegaraan itulah yang disebut sebagai nasionalisme. Berdasarkan latar itu tampak bahwa nasionalisme A. Hasjmy adalah nasionalisme Indonesia yang berasaskan keacehan. Simbol keacehan melatari upaya meraih cita-cita nasional Indonesia. Jadi, keacehan beliau jadikan sebagai pangkal bertolak. Karya-karya beliau tidak lahir dalam kekosongan, melainkan dipersiapkan dengan saksama, baik berupa pengalaman A. Hasjmy sendiri, hasil pengamatan langsung, maupun hasil bacaan beliau terhadap literatur yang sejalan dengan tema karangan.

Secara kronologis, tahapan perkembangan kepengarangan A. Hasjmy dapat dibagi ke dalam lima periode. Pertama, zaman penjajahan Belanda (1914-1942), yang merupakan masa penuh dinamika bagi A. Hasjmy untuk belajar agama dalam keluarga dan di sekolah, belajar berorganisasi dan berpolitik selama dua kurun di Sumatera Barat, dan melahirkan lima buah novel, tiga puluhan cerpen, dan dua kumpulan puisi. Kedua, zaman penjajahan Jepang (1942-1945), yang merupakan zaman pematangan pengalaman berorganisasi bagi A. Hasjmy seperti organisasi keagamaan, kepramukaan, organisasi politik dan organisasi bawah tanah, serta bekerja sebagai guru, kepala polisi, wartawan, dan pengarang sebuah novel. Ketiga, zaman revolusi (19451949), yang merupakan masa pematangan jiwa dan pikiran dan beliau lebih memberi perhatian kepada kerja sebagai wartawan, pegawai negeri, birokrat, anggota DPR dan militer, serta menerbitkan sebuah kumpulan puisi. Keempat, akhir masa Orde Lama (1950-1966), yang merupakan masa kematangan karier politik. Dalam masa ini beliau mengambil peranan dalam berbagai lapangan kebangsaan dan kenegaraan seperti menjadi gubernur Aceh dan terlibat dalam perdamaian DI/TII melalui misi Hardi. Dalam bidang kreatif beliau melahirkan dua novel pendek, satu kumpulan puisi, satu karya analisis sastra, dan sebuah kumpulan surat dari penjara. Kelima, zaman Orde Baru (1966-1998), yaitu masa yang sangat produktif bagi A. Hasjmy karena beliau menghasilkan dua novel dan empat kumpulan puisi, di samping terlibat dalam dunia akademik.

Latar kepengarangan ini memperlihatkan bahwa A. Hasjmy sangat produktif dalam melahirkan karya sastra, yaitu 11 kumpulan puisi, 11 novel, dan 32 buah cerpen. Dari kesebelas novel tersebut, hanya tujuh novel yang dapat ditemukan, yaitu ketujuh novel yang diteliti dalam kajian ini. Empat buah novel selain itu tidak dapat ditemukan, yaitu Sayap Terkulai (roman perjuangan, 1938?) Di Bawah Naungan Pohon Kemuning (roman sejarah, 1940), Cinta Mendaki (roman falsafah/perjuangan, 1941), dan Dewi Fajar (roman politik, 1943).

\section{Doktrin Nasionalisme}

Berdasarkan kajian terhadap ketujuh novel tersebut, berkaitan dengan isu doktrin nasionalisme, didapati beberapa rumusan. Pertama, doktrin nasionalisme sebagaimana tercermin dalam novel-novel A. Hasjmy merupakan gambaran dari konsep atau paham kebangsaan yang mewujud dalam unsur otonomi nasional, kesatuan nasional, dan identitas bangsa.

\section{Otonomi nasional}

Bagi A. Hasjmy, otonomin nasional adalah kebebasan, kemerdekaan, dan kemandirian dalam berbagai aspek kehidupan berbangsa dan bernegara, termasuk kebebasan dalam beragama, berbicara dan berpendapat, berkelompok dan berorganisasi. Hal ini menjadi asas bagi A. Hasjmy dalam pengungkapan sikap antikolonial dan antifeodal. Hal ini dapat dipilah ke dalam tiga 
zaman, yaitu zaman prakolonial, zaman kolonial, dan zaman revolusi. Hal ini direfleksikan melalui kisah perang gerilya (SALG), kisah penawanan dan pembuangan para pejuang (SALG, TM), narasi mengenai perilaku kejam Belanda (SALG, EGN, NP, TM), kebiadaban dan tanpa perikemanusiaan situasi tanah buangan dan penjara (TM). Hal senada lainnya adalah upaya propaganda Belanda melalui generasi akhir kaum feodal yang berkehendak mendirikan 'negara boneka merdeka', kerja sama sekutu dan gigihnya perjuangan rakyat, dan propaganda dan kontra revolusi para mata-mata (NP \& EGN). Semua ini dikemas oleh A. Hasjmy guna menunjukkan konsep otonomi nasional dengan membina rasa antipati terhadap eksistensi kaum penjajah di bumi Indonesia. Di dalam dua novel terawal, yaitu MJRD dan BCB, A. Hasjmy hanya memasukkan unsur kebebasan beragama, sementara hal-hal yang bersifat politik kurang mendapat perhatian, meskipun novel ini ditulis semasa Indonesia masih dijajah Belanda. Sementara itu, di dalam novel MJ, gambaran otonomi itu disebutkan, tetapi bukan dalam konteks zaman Indonesia, melainkan disemat dalam kerangka masuknya Islam ke Banda Aceh. Di dalam novel-novelnya yang lain, yaitu SALGNP-EGN-TM, topik ini dibicarakan secara saksama dan meluas. Kesaksamaan dan keluasan bahasan tersebut mengindikasikan bahwa masalah otonomi dalam makna kebebasan, kemerdekaan, dan kemandirian ini merupakan salah satu inti dari doktrin nasionalisme A. Hasjmy.

\section{Kesatuan Nasional}

Kesatuan (unity) bagi A. Hasjmy mencakup kesatuan wilayah atau tanah air, kesatuan bangsa, kesatuan bahasa, kesatuan ideologi dan doktrin kenegaraan, kesatuan sistem pertahanankeamanan, dan kesatuan dalam lingkup kebudayaan. Kesatuan wilayah atau tanah air terungkap melalui pengakuan akan kewujudan tanah air dan pemujaan akan keindahan alam tanah air, yaitu tanah air Indonesia yang terbentang dari Sabang (Aceh) hingga Merauke (Irian Jaya). Kesatuan bangsa merupakan kesatuan pelbagai etnik dengan adat dan budayanya yang tersendiri, yang mendiami seluruh kepulauan nusantara, yaitu bangsa Indonesia. Kesatuan bangsa ini antara lain diungkapkan melalui perkawinan antaretnik warga nusantara. Kesatuan bahasa bermakna penjanjungan terhadap bahasa persatuan, yaitu bahasa Indonesia (SALG). Kesatuan ideologi dan doktrin kenegaraan bagi A. Hasjmy mengarah kepada penganutan ideologi dan negara Islam, yang dalam perkembangannya beliau harus menerima ideologi Pancasila dalam lingkungan
Negara Kesatuan Republik Indonesia. Kesatuan dalam lingkup kebudayaan adalah kesatuan dalam arti bhinneka tunggal ika 'walau beraneka namun satu jua'. Dengan ini nyatalah bahwa doktrin nasionalisme dalam novel-novel A. Hasjmy dalam kaitannya dengan unsur kesatuan mencerminkan konsep dan proses integrasi berdasarkan solidaritas nasional yang melampuai solidaritas lokal dan etnik. Persoalan kesatuan tersebut dapat dijumpai di dalam ketujuh-tujuh novel A. Hasjmy. Secara jelasnya kesatuan yang dimaksudkan oleh A. Hasjmy merujuk kepada Indonesia. Tiga buah novel sebelum Indonesia merdeka, yaitu MJRD-BCB-SALG, secara nyata menggambarkan ke-Indonesiaan itu. Manakala dua buah novel semasa revolusi (semasa awal Indonesia merdeka), yaitu NP-EGN, semakin memperkuat gagasan yang dimaksudkan. Selanjutnya, dua buah novel terakhir, yang lahir ketika Indonesia sedang membangun, yaitu MJTM, menunjukkan kematangan ke-Indonesiaan itu dengan meninjau peristiwa masa silam, ketika Indonesia belum terbentuk (MJ) dan ketika perjuangan merebut kemerdekaan (TM).

\section{Identitas Bangsa}

Identitas bangsa dalam novel-novel A. Hasjmy direfleksikan dalam wujud simbol atau metafora, baik simbol organisasi (BCB, SALG, EGN, NP, TM), simbol tokoh (MJRD, SALG, EGN, NP, MJ, TM), simbol adat dan budaya (MJRD, SALG, TM), maupun metafora (sejarah) etnik (SALG, NP, MJ, TM). Meskipun begitu, keadaan tersebut menyiratkan bahwa karya kreatif A. Hasjmy tidak begitu terpengaruh oleh konsep etnonasionalisme, nasionalisme lokal, termasuk nasionalisme keacehan. Latar keacehan atau etnik lainnya digunakan untuk merujuk kepada identitas sebagai wujud doktrin nasionalisme keindonesiaan. Keadaan ini pun dilihat dalam pelbagai dimensi, yaitu dimensi moralitas, histori, kultural, dan sebagainya, yang melekat pada ciriciri kedaerahan atau kepribadian etnik sebagai refleksi identitas bangsa. Misalnya, Aceh dikenalkan sebagai negeri yang makmur, rakyat dan pemimpinnya memiliki sifat ksatria yang luar biasa dalam melawan berbagai kejahatan, bersahabat dengan semua bangsa di dunia, agamis dan sekaligus antikomunis, sehingga akhirnya menjadi modal dan asas nasionalisme Indonesia. Kesemuanya ini dibangun dalam kerangka penyematan harga diri, rasa bangga, dan rasa cinta terhadap identitas dan kepribadian bangsa. Ini semua digali jauh menukik ke dalam sejarah peradaban dan pernik-pernik kehidupan berbagai etnik yang ada.

Kajian ini menemukan bahwa nasionalisme yang tercermin di dalam novel-novel A. Hasjmy adalah 
nasionalisme Indonesia, yaitu semangat kebangsaan yang mendukung negara-bangsa Indonesia Raya. Temuan ini membayangkan bahwa sebagian penduduk Aceh, termasuk A. Hasjmy, tidak begitu menyokong nasionalisme keacehan seperti yang didukung oleh gerakangerakan pembebasan Aceh. Meskipun begitu, sikap keindonesiaan beliau bermula dan dipengaruhi oleh semangat keacehan. Pembayangan nasionalisme Indonesia itu dilakukan dalam alur sistematik seperti berikut. Awal sekali, A. Hasjmy menunjukkan jati diri individu tokoh yang menjadi watak novel sebagai pencerminan kepada watak individu etnik di dunia nyata. Kemudian, individu itu beliau kembangkan ke arah perefleksian eksistensi komunitas etnik tertentu di kepulauan nusantara, terutama untuk mewakili etnik Aceh. Akhirnya, barulah beliau menunjukkan tubuh bangsa melalui sikap solidaritas nasional Indonesia.

Posisi pengarang, yaitu A. Hasjmy, dalam konteks nasionalisme Indonesia itu ialah sebagai penggagas dan aktivis nasionalis. Hal ini sejalan dengan kehidupan nyata beliau. A. Hasjmy telah mengambil peranan dalam perjuangan dan pergerakan kebangsaan, baik dalam zaman prakemerdekaan maupun dalam zaman pascakemerdekaan Indonesia. Dalam konteks Aceh, pendapat atau pandangan A. Hasjmy dalam hal tertentu terlihat berbeda dengan pandangan sejumlah tokoh pergerakan pembebasan Aceh seperti Daud Beureu-eh (tokoh DI/TII Aceh) atau Hasan Di Tiro (tokoh GAM). A. Hasjmy selalu mengambil posisi pada kebangsaan dalam konteks Indonesia, sementara sebagian tokoh yang lain lebih memperjuangkan Aceh sebagai wilayah berdaulat dan terpisah dari Indonesia. Persamaan pandangan di antara mereka (para tokoh tersebut) terutama terletak pada penempatan Islam sebagai dasar pijakan dalam pembinaan negara-bangsa. Oleh karena nasionalisme yang dianuti oleh A. Hasjmy agak bertentangan dengan apa yang dipegang dan dikampanyekan oleh pendukung pembebasan Aceh menyebabkan beliau menyampaikan pandangan nasionalismenya secara halus, yaitu melalui teknik penulisan yang berbentuk surat, pidato, catatan harian, puisi, dan catatan kaki. Dengan temuan ini, kajian ini boleh dianggap penting karena ia dapat menjelaskan secara ilmiah bahwa tidak semua penduduk Aceh terpengaruh dengan gerakan kemerdekaan untuk memisahkan provinsi itu dari negara-bangsa Indonesia.

A. Hasjmy menggunakan latar sejarah sebagai bahan utama novel-novel tersebut. Narasi sejarah digunakan untuk mengangkat ingatan-ingatan tentang kemajuan-kemajuan yang telah dicapai pada masa lampau, dengan aspirasi-aspirasi bagi kebesaran bangsa pada masa yang akan datang. Artinya, A. Hasjmy membangkitkan kesadaran kebangsaan berdasarkan memori kolektif masa lalu sekaligus menunjukkan langkah-langkah yang mendorong harapan-harapan untuk masa depan. Dalam kaitan inilah penelitian memperlihatkan bahwa teori nasionalisme dari para pakar seperti Anderson, Kohn, Smith, atau Breuilly dapat digunakan dalam menganalisis karya-karya A. Hasjmy. Teori Anderson berkenaan dengan konsep bahwa bangsa adalah komunitas yang direkabayangkan dan karya sastra telah mengambil peranan dalam pembayangan itu. Anderson juga berprinsip bahwa nasionalisme selalu melihat masa silam sekaligus menatap masa depan. Sebagai karya sastra, novel-novel A. Hasjmy berperanan dalam merefleksikan kehidupan komunitas zaman karya itu dihasilkan, terutama dalam mengesankan doktrin atau paham, sentimen atau perasaan, dan pergerakan kebangsaan yang disebut nasionalisme itu sebagaimana tersimpul dari Kohn, Smith, Breuilly. Secara akademik dapat dibuktikan kebenaran teori sosiologi sastra yang menyebutkan bahwa karya sastra merekam realitas kehidupan.

Di samping itu, terutama sejalan dengan teori nasionalisme Smith, novel-novel A. Hasjmy menunjukkan bahwa bangsa merupakan penjelmaan modern dari sentimen etnik yang tersembunyi dalam sejarah. Nasionalisme turut mendorong sentimen komunal etnik itu dalam menata masa depan. Dengan begitu, bagi A. Hasjmy nasionalisme merupakan gerakan pencarian identitas dan genealogi komunitas kolektif di masa lalu sekaligus pencarian arah kolektif ke masa depan. Bagi A. Hasjmy, akar-akar masa lalu etnik seperti nilai, mitos kepahlawanan, dan simbol-simbol etnik lainnya memiliki peranan yang lebih sentral dalam memahami bangsa dan semangat kebangsaan. A. Hasjmy mengesankan nasionalisme dengan menunjukkan perbedaan antara etnik, tetapi juga menghendaki persatuan mereka, yaitu mempersatukan Melanesia di timur (Irian Jaya) sehingga Melayu di barat, yang diandaikan sebagai bangsa dan negara bernama Indonesia. Dengan itu, penelitian ini memberi sumbangan dalam pamahaman karya sastra dalam kaitannya dengan negarabangsa.

\section{PENUTUP}

Penelitian ini menyimpulkan beberapa hal berikut. Pertama, doktrin nasionalisme yang tercermin dalam novel-novel A. Hasjmy adalah nasionalisme Indonesia, yaitu semangat kebangsaan yang mendukung negara-bangsa 
Indonesia. Kedua, posisi A. Hasjmy dalam konteks doktrin nasionalisme itu ialah sebagai penggagas dan aktivis nasionalis. Ketiga, A. Hasjmy menggunakan latar sejarah sebagai bahan utama novelnya.

Berasaskan penemuan-penemuan di atas, peneliti memberikan beberapa rekomendasi sebagai tindak lanjut dari penelitian ini. Pertama, A. Hasjmy adalah pengarang karya kreatif baik berbentuk novel, cerpen, maupun puisi. Ternyata bahwa novel-novel hasil karya A. Hasjmy berisikan nasionalisme. Artinya, karya novel di sini berperanan dalam mengungkap nasionalisme. Penelitian nasionalisme dalam karya puisi atau cerpen A. Hasjmy patut dilakukan. Kedua, penelitian ini terbatas pada analisis doktrin nasionalisme dalam novel-novel
A. Hasjmy. Novel sebagai karya sastra tentu saja tidak hanya berisi nasionalisme. Penelitian masalah selain doktrin nasionalisme dalam novel-novel A. Hasjmy dapat digalakkan. Ketiga, penelitian ini berkesimpulan bahwa A. Hasjmy adalah penganut nasionalisme dalam bingkai nasional Indonesia dan bukan etnonasionalisme Aceh. Sebaliknya, sudah umum diyakini orang bahwa sebahagian komunitas Aceh selain A. Hasjmy sering diisukan sebagai berbeda pandangan terhadap Indonesia. Penelitian ini telah menunjukkan tempat yang wajar bagi $\mathrm{A}$. Hasjmy yang sesuai dengan gagasan dan kehidupan nyatanya sebagai sastrawan dan negarawan. Oleh itu, penelitian dari segi politik terhadap tokoh-tokoh Aceh termasuk sastrawan selain A. Hasjmy masih amat signifikan.

\section{DAFTAR PUSTAKA}

Blair, F. 1990. Survay on Shoestring. Arlington, The Summer Institute of Linguistics and The University of Texas at Arlington, Texas.

Casad, Eugene. 1992. Windows on Bilingualism, The Summer Institute of Linguistics and The University of Texas at Arlington, Texas.

Darjo, Wijoyo S. 1985. Perkembangan Linguistik Indonesia. Jakarta: Arcan.

Francis, W.N. 1983. Dialectology. London: Logman Group Limited.

Friberg, T. 1985. A Dialect Geography of Bugis. Papers in Western Austronesian

Linguistics no. 4.

Grimes, B.F. 1988. The Ethnologue: Linguage of the World. 11 ${ }^{\text {th }}$ Edition. Dallas: Summer Institute of Linguistics.

Grimes, C.E. and B.D Grimes. 1987. Linguage of South Sulawesi. Canberra: Pacific Linguistics Series DNo.78, The Australian Nation University,

Grimes, J.E. 1989. Wedening Sircle of Communication. In Ted Bragman (ed), International Engglish Assessment Confrence, Horsleys Green, England, 24-31 May 1989. Dallas: Summer Institute of Linguistics.

Inghoung A. Sofyan, dkk. 1980. Sistem Morfologi Kata Kerja Bahasa Kaili. Ujung Pandang: Proyek Penelitian Bahasa dan Sastra Indonesia dan Daerah Sulwesi Selatan.

Inghoung A. Sofyan. 1979. Morfologi dan Sintaksis Bahasa Kaili. Ujung Pandang: Proyek Penelitian Bahasa dan Sastra Indonesia dan Daerah Sulawesi Selatan.

Lehmann, W.P. 1973. Historical Linguistics: An Introduction. Second Edition. New York: Holt, Rinehart and Winston.

Masyhuda, M. 1971. Ikhtisar Imbuhan dalam Bahasa Kaili Dialek Palu. Palu: Yayasan Kebudayaan Sulawesi Tengah.

Mills, R. 1979. Proto South Sulawesi and Proto Austronesian Fonology (2 Vols.). Ann Arbor: University Microfilms International.

Muhadjir dan Lauder. 1992. dalam Muhadjir, dkk. (ed). Transformasi Budaya Seperti Tercermin dalam Perkembangan Bahasa-bahasa di Indonesia. Jakarta: Fakultas Sastra Universitas Indonesia. 
Nasution, S. 2000. Metode Research. Jakarta: Bumi Aksara.

Ponulele, N.W. 1970. An Analitical Study on The Kaili Language. Skripsi Sarjana. Ujung Pandang: FKSS-IKIP Ujung Pandang.

Samsuri. 1987. Analisa Bahasa. Jakarta: Erlangga.

Simon, L. 1989. Language Variation and Limit to Communication. Ithaca: DMLL, Cornell University, Reissues by Summer Institute of Linguistics.

Swadesh, M. 1955. Toward Greater Accurancy in Lexicostatistic Dating. International Journal of American Linguistics.

Voegelin, C.F and Z.S Harris. 1978. Method for Determining Intelligibility Among Dialects of Natural Languages. Proceedings of The American Philosophical Society, 95:322-9.

Wolf, H. 1959. Intelligibility and Inter-ethnic Attitudes. Anthropological Linguistics 1(3):34-41. Repriented in Language in Cultur and Society, Edited by Dell Hymes, 1964.pp. 440-5. 